\title{
CULTIVATION OF OYSTER MUSHROOM: A SUSTAINABLE APPROACH OF RURAL DEVELOPMENT IN NEPAL
}

\section{Chandra P. Pokhrel}

Journal of Institute of Science and Technology

Volume 21, Issue 1, August 2016

ISSN: 2469-9062 (print), 2467-9240(e)

Editors:

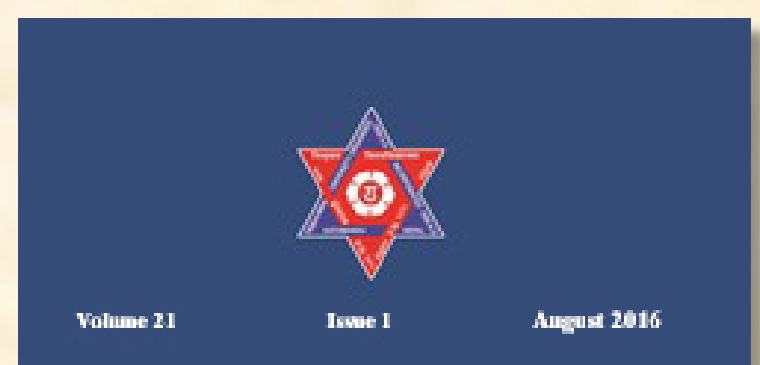

Prof. Dr. Kumar Sapkota

Prof. Dr. Armila Rajbhandari

Assoc. Prof. Dr. Gopi Chandra Kaphle

JIST, 21 (1), 56-60 (2016)

JOURNAL OF INSTITUTE OF SCIENCE AND TECHNOLOGY
Published by

Institute of Seience and Teehnology

Tribhuvan University

Kirtipur, Kathmanda, Nepal

Published by:

Institute of Science and Technology

Tribhuvan University

Kirtipur, Kathmandu, Nepal 


\title{
CULTIVATION OF OYSTER MUSHROOM: A SUSTAINABLE APPROACH OF RURAL DEVELOPMENT IN NEPAL
}

\author{
Chandra P. Pokhrel \\ Central Department of Botany, Tribhuvan University, Kirtipur, Nepal \\ Corresponding email: chandraprkh@yahoo.com
}

\begin{abstract}
This study attempts to investigate the easily acceptable and low cost technology of Oyster mushroom cultivation. Locally and easily available substrates such as corn cob, vegetable residue and waste paper were examined with the supplementation of rice bran and chicken manure separately. During the study mycelial growth, spawn run, pin head formation, yield and biological efficiency were observed. Best mycelial extension, early pin head formation and better yield were observed in corn cob substrate followed by paper waste and vegetable residue. Among the substrates used, corn cob showed the highest yield with range from 99.08 to $109.50 \%$ biological efficiency, whereas 69.81 to $88.36 \%$ and 52.26 to $65.22 \%$ biological efficiency was observed in paper waste and vegetable residue respectively. Rice bran was the best supplement for the promotion of growth and development of Oyster mushroom.
\end{abstract}

Keywords: Low cost technology, Oyster mushroom, Sustainable approach, Biological efficiency

\section{INTRODUCTION}

Mushrooms are saprophytic fungi growing on dead organic matters of vegetative origin and can utilize almost all forest and agricultural residues as substrates (Adejoye et al. 2006). Pleurotus spp, commonly known as Oyster mushroom, are decomposer of wood and vegetable residues (Zadrazil \& Kurtzman 1981). In nature, Pleurotus ostreatus is active lignin degrader in the forest therefore it appears in cluster on dead trees from late fall to spring. It is distributed all over the world especially in subtropical and temperate forests zone.

The consumption of mushrooms by humans is an age-old practice. However, in recent days mushroom has become a part of every continental dish because of its good taste, flavor and nutritional value. It contains large amount of nutrients, proteins, vitamins, minerals, fiber etc., and hence can be considered as pool of nutrients. The discovery of bio-active compounds, including antitumor substances has stirred a growing interest in such mushrooms from industry, the media and the scientific community (Pokhrel et al. 2006).

Cultivation of Oyster mushroom with agricultural residues, such as rice and wheat straw is a value added process to convert these materials into human food (Pokhrel et al. 2013). It represents one of the most efficient biological ways by which these residues can be recycled (Madan et al. 1987). Mushroom cultivation not only helps to reduce the protein deficiency especially in developing countries like Nepal but also increases income of the rural poor people. The objectives of rural development in developing countries are mainly diversification of rural income and attaining a competitive structure for agriculture in order to increase job opportunities and development (Sharma et al. 2013). Mushroom cultivation can be a big source of income through rural development program for farmers if they are made aware its cultivation process and its importance. By taking into consideration of drought and food and nutrition security problems in some countries, mushroom production could be an alternative source to overcome these problems. In addition, livelihood can be improved because the demand of mushroom has been increasing due to increasing population, market expansions and changing of consumer behavior (Celik \& Pekker 2009). The raw materials which can be applied for Oyster mushroom cultivation are cheaply available in farmer's yards and easily cultivated in various climatic conditions as a fast maturing crops. Therefore the aim of the study is to evaluate the growth and yield of $P$. osteratus on locally available substrates with supplementation in ambient environmental conditions which can be easily applied by farmers from hinterlands. 


\section{MATERIALS AND METHODS}

The spawn of P. ostreatus was obtained from Nepal Agricultural Research Council (NARC) Khumaltar, Nepal. The used strain is commercially supplied by NARC. The preparation of substrate from the raw materials was based on dry weight basis. Corn cob, paper waste (print paper waste) and vegetable residue were the substrate used in this research and mixed with supplement. At first, the paper waste was collected from the premises of Tribhuvan University, Kirtipur, which were dumped during the student's election. Corn cob was brought from Kanchanpur district. Vegetable residue was collected from Kalimati vegetable market. All the substrates were chopped into small pieces and separately supplemented with chicken manure and rice bran at the proportion of 9:1 (w:w) and mixed thoroughly. The substrate without supplement was considered as control. Each of these treatments along with control was replicated five times during the experiment. Those mixtures were then soaked in tap water for about three hours and moisture was adjusted to about $60-65 \%$. One $\mathrm{kg}$ of wet substrate was placed into polypropylene bag of dimension $20 \mathrm{~cm} \times 15 \mathrm{~cm}$ and autoclaved at $121^{\circ} \mathrm{C}$ for one hour and was allowed to cool overnight. Each bag was inoculated with $3 \% \mathrm{w} / \mathrm{w}$ of grain spawn and the mouth of the bags were closed with cotton plug and tied with rubber band. Inoculated bags were then kept in dark room at the room temperature of $15-$ $19^{\circ} \mathrm{C}$. After the substrate has been colonized with mycelium the polypropylene bags were cross slashed to allow the mushroom to grow out. These bags were watered (sprayed) twice a day to maintain humidity as well as moisture.
Mycelial growth was observed regularly and growth was recorded on weekly basis. Days to colonization, pinhead and fruit body formation were also recorded. Mushroom yield was recorded by weighing the fresh mushroom. The numbers of mushroom produced were counted. Besides, the weight size and biological efficiency (BE) were also determined. The data were recorded for the first and second flushes. Yield was determined by weighing and counting of fruit bodies. BE was calculated as fresh weight of harvested mushrooms (g) / dry weight of substrate $\times 100$.

The size of mushrooms was calculated by total weight of fresh mushroom harvested/total number of mushroom harvested (Pokhrel et al. 2013).

\section{RESULTS}

Mycelia extension on different substrates with supplements is shown in Table 1. Corn cob showed the faster mycelium run with rice bran supplement $(20.50 \mathrm{~cm})$ followed by chicken manure $(19.25 \mathrm{~cm})$ and control $(18.40 \mathrm{~cm})$ in four-week incubation. Paper waste supplemented with rice bran showed faster mycelial growth $(18.00 \mathrm{~cm})$ during the spawn run followed by chicken manure $(17.00 \mathrm{~cm})$ and control $(17.00 \mathrm{~cm})$. Vegetable residue supplemented with rice bran showed higher mycelial growth $(16.94 \mathrm{~cm})$ followed by chicken manure supplement $(15.71 \mathrm{~cm})$ and control $(15.53$ $\mathrm{cm})$. Among all substrates used, corn cob was the best substrate followed by paper waste and vegetable residue for mycelia extension. Similarly rice bran showed the best supporter of growth.

Table 1. Comparison of weekly mycelial growth of $\boldsymbol{P}$. osteratus on different substrates $($ Mean \pm SD n=5).

\begin{tabular}{llcccc}
\hline Substrates & \multicolumn{1}{c}{ Supplements } & $\begin{array}{c}\text { I week } \\
(\mathbf{c m})\end{array}$ & $\begin{array}{c}\text { II week } \\
(\mathbf{c m})\end{array}$ & $\begin{array}{c}\text { III week } \\
(\mathbf{c m})\end{array}$ & IV week $(\mathbf{c m})$ \\
\hline Corn cob & Control & $4.12 \pm 0.3$ & $8.32 \pm 0.1$ & $12.60 \pm 0.6$ & $18.40 \pm 0.2$ \\
& Rice bran & $4.75 \pm 0.5$ & $8.62 \pm 1.1$ & $16.00 \pm 1.4$ & $20.50 \pm 1.5$ \\
& Chicken manure & $4.27 \pm 0.5$ & $8.57 \pm 1.1$ & $12.85 \pm 2.1$ & $19.25 \pm 2.9$ \\
\hline Vegetable & Control & $3.96 \pm 0.6$ & $7.14 \pm 0.8$ & $11.06 \pm 1.3$ & $15.53 \pm 1.2$ \\
residue & Rice bran & $4.15 \pm 0.2$ & $7.08 \pm 0.5$ & $11.89 \pm 1.3$ & $16.94 \pm 1.1$ \\
& Chicken manure & $4.04 \pm 0.5$ & $7.72 \pm 0.5$ & $11.31 \pm 1.6$ & $15.71 \pm 2.2$ \\
\hline Paper & Control & $3.38 \pm 0.3$ & $8.00 \pm 1.2$ & $12.37 \pm 2.2$ & $17.00 \pm 0.4$ \\
waste & Rice bran & $4.27 \pm 0.3$ & $8.34 \pm 0.3$ & $12.54 \pm 0.3$ & $18.00 \pm 0.6$ \\
& Chicken manure & $3.64 \pm 0.5$ & $8.05 \pm 0.7$ & $12.54 \pm 0.3$ & $17.00 \pm 0.4$ \\
\hline
\end{tabular}


Days for colonization, primordial formation and first harvest were different in each substrate with supplements. The fastest colonization period (34 days), primordial formation period (37.10 days) and first harvest period (40.20 days) were recorded from corn cob with rice bran supplement whereas the slowest colonization period (39 days), primordial formation period (44.80 days) and first harvest period (48.70 days) was found in vegetable residue (control) among all treatments (Table 2).

Table 2. Comparison of colonization period, primordial formation and first harvest days of $\boldsymbol{P}$. osteratus on different substrates (Mean $\pm \mathrm{SD}, \mathrm{n}=5$ ).

\begin{tabular}{lllll}
\hline Substrates & \multicolumn{1}{c}{ Supplements } & $\begin{array}{c}\text { Colonization } \\
\text { (days) }\end{array}$ & $\begin{array}{c}\text { Primordial } \\
\text { formation (days) }\end{array}$ & $\begin{array}{c}\text { First harvest } \\
\text { (days) }\end{array}$ \\
\hline Corn cob & Control & $35.00 \pm 0.1$ & $38.00 \pm 1.0$ & $41.40 \pm 0.6$ \\
& Rice bran & $34.00 \pm 0.3$ & $37.10 \pm 0.5$ & $40.20 \pm 1.0$ \\
& Chicken manure & $36.20 \pm 1.0$ & $39.20 \pm 1.3$ & $43.80 \pm 1.0$ \\
\hline Paper & Control & $36.25 \pm 0.8$ & $39.21 \pm 0.5$ & $43.00 \pm 1.0$ \\
& Rice bran & $35.80 \pm 1.1$ & $38.00 \pm 1.5$ & $41.40 \pm 2.0$ \\
& Chicken manure & $36.10 \pm 0.7$ & $40.20 \pm 0.1$ & $44.20 \pm 2.1$ \\
\hline Vegetable & Control & $39.00 \pm 1.0$ & $44.80 \pm 3.1$ & $48.70 \pm 3.0$ \\
residue & Rice bran & $37.10 \pm 0.4$ & $42.00 \pm 2.1$ & $45.30 \pm 1.8$ \\
& Chicken manure & $38.20 \pm 1.3$ & $43.40 \pm 2.0$ & $47.60 \pm 2.8$ \\
\hline
\end{tabular}

Two flushes yield were recorded during the experiments. The study showed that different substrate and supplements influenced varying yields. Total yield, BE and mushroom size are presented in Table 3. The total yield in corn cob with rice bran $(602.50 \mathrm{~g})$ was highest followed by chicken manure $(545 \mathrm{~g})$ and control $(506 \mathrm{~g})$ respectively. Following the corn cob second highest yield was recorded from paper waste with rice bran supplement (486g), with chicken manure supplement $(430 \mathrm{~g})$ and control $(385 \mathrm{~g})$. The total yield was recorded in vegetable residue with rice bran supplement $(358.70 \mathrm{~g})$ and chicken manure supplement (303.75g) and control (287.50g).
Among three different substrates best yield was recorded from corn cob followed by paper waste and vegetable residue, where as rice bran was the best supplement which is consistent in all substrates used in the experiment. The biological efficiencies ranged from 91.99 to $109.50 \%$ in corn cob, similarly 69.81 to $88.36 \%$ in paper waste and 52.26 to $65.22 \%$ in vegetable residue. In comparison to second flushes, yield was higher in the first flush in all substrates. The larger size of mushroom was recorded from vegetable residue with control $(10.31 \mathrm{~g})$ whereas smaller size was found in paper waste with chicken manure supplement $(6.08 \mathrm{~g})$ among all the treatments.

Table 3. First and second flush of $P$. osteratus on different substrates (Mean $\pm \mathrm{SD}, \mathrm{n}=\mathbf{5}$ )

\begin{tabular}{|c|c|c|c|c|c|c|}
\hline \multicolumn{2}{|c|}{$\begin{array}{l}\text { Substrates and } \\
\text { Supplement }\end{array}$} & $\begin{array}{l}\text { First flush } \\
\text { (g) }\end{array}$ & $\begin{array}{l}\text { Second flush } \\
\text { (g) }\end{array}$ & $\begin{array}{c}\text { Total Yield } \\
\text { (g) }\end{array}$ & $\begin{array}{c}\text { Biological } \\
\text { efficiency } \\
(\%)\end{array}$ & $\begin{array}{l}\text { Mushroom } \\
\text { size (g) }\end{array}$ \\
\hline \multirow[t]{3}{*}{ Corn cob } & Control & $316.00 \pm 18.2$ & $190.00 \pm 7.90$ & $506.00 \pm 13.9$ & $91.99 \pm 2.5$ & $8.15 \pm 0.7$ \\
\hline & Rice bran & $352.50 \pm 11.9$ & $250.00 \pm 15.81$ & $602.50 \pm 23.2$ & $109.50 \pm 4.2$ & $8.05 \pm 0.2$ \\
\hline & Chicken manure & $339.00 \pm 16.7$ & $206.00 \pm 5.5$ & $545.00 \pm 18.17$ & $99.08 \pm 3.4$ & $8.91 \pm 0.4$ \\
\hline & $234.00 \pm 8.9$ & $151.00 \pm 12.7$ & $385.00 \pm 18.5$ & $69.81 \pm 3.4$ & $6.35 \pm 0.2$ \\
\hline \multicolumn{2}{|c|}{$\begin{array}{r}\text { Rice bran } \\
\text { Ricentrol }\end{array}$} & $289.00 \pm 7.4$ & $190.70 \pm 10.4$ & $486.00 \pm 14.7$ & $88.36 \pm 2.7$ & $8.23 \pm 0.8$ \\
\hline & Chicken manure & $243.00 \pm 7.6$ & $177.00 \pm 12.5$ & $430.00 \pm 19.1$ & $76.35 \pm 3.5$ & $6.08 \pm 0.2$ \\
\hline \multicolumn{2}{|c|}{ Vegetable Control } & $186.25 \pm 9.5$ & $101.25 \pm 8.5$ & $287.50 \pm 6.5$ & $52.26 \pm 1.2$ & $10.31 \pm 0.6$ \\
\hline \multirow[t]{2}{*}{ Residue } & Rice bran & $197.50 \pm 14.4$ & $161.25 \pm 21.0$ & $358.70 \pm 534.2$ & $65.22 \pm 6.2$ & $10.09 \pm 0.6$ \\
\hline & Chicken manure & $190.00 \pm 14.7$ & $113.75 \pm 9.5$ & $303.75 \pm 22.9$ & $55.22 \pm 4.2$ & $10.13 \pm 0.6$ \\
\hline
\end{tabular}




\section{DISCUSSION}

Growing Oyster mushrooms are becoming more popular throughout the world because of their abilities to grow at a wide range of temperature utilizing various lingo-cellulose materials (Pidgeon \& Anderson 1981, Mueller \& Gawley 1983). The capacity of Pleurotus species to grow on agricultural residue is due to their ligninolytic enzymes and other adaptive enzymes which are generally necessary for completion of fungal life cycle (Martinez et al. 1994, Jenning \& Lysek 1999). Mycelial growth is a fundamental step that creates suitable internal conditions for mushroom cultivation. Thus, excellent growth of mycelium is a very important factor in mushroom cultivation (Pokhrel et al. 2009). Fastest mycelial extension, early pin head formation and better yield were observed in corn cob substrate followed by paper waste and vegetable residue respectively. In all substrates, mycelial growth was highly influenced by rice bran supplement compared to chicken manure, whereas poor growth was observed in control. This study revealed that addition of supplements not only enhance the growth and development of mycelia or spawn running but also enhance pin head development, fruit body formation and mushroom yield. Das and Mukherjee (2007) analyzed that organic supplements such as rice bran mixed with Leonotis species as substrate increased not only growth parameter but also increased the yield of mushroom of $P$. ostreatus. Baysal et al. (2003), reported spawn running, pin head formation and fruit body development and mushroom yield of Oyster mushroom on waste paper substrate with chicken manure and rice bran. In this study fast mycelial growth and better yield may be due to the high quality nutritional value in combination of both substrate as a corn cob and rice bran as a supplement and followed by paper wastes and vegetable residue with rice bran. In addition to that, higher levels of water soluble sugars in corn cob, particularly hemicelluloses could induce higher growth, prior to the breakdown of lignin and cellulose. In return, the highly colonized substrate had high mycelial density. This result is supported by the result of Philippoussis et al. (2006). They found that the mycelia growth and yield of Lentinula edodes were high in different substrates with different supplements. Zhang et al. (2002) studied Pleurotus sajar-caju mushroom cultivation in two substrates, rice straw and wheat straw in the two forms of grinding and chopping and he observed that ground rice straw yielded higher mushroom growth rate than the chopped straw. This is because it ruptured the cell wall of the straw to a greater degree, potentially making the nutrients in the straw more accessible for mushroom growth. Similar result was obtained in our study because the ground forms of corn cob substrate showed fast mycelial growth, primordial formation, fruiting bodies formation and highest yield of mushroom. In the present result, the fruiting bodies appeared 3-5 weeks after primordial formation and took 34-46 days after inoculation of spawn. These findings are in conformity with those of Tan (1981), who reported that $P$. ostreatus and other species on cotton waste took 2-3 weeks for fruit body formation after the colonization of substrate.

\section{CONCLUSIONS}

Mushrooms are very rich source of protein and hence could be more effective in decreasing protein deficiency as well as malnutrition problem in rural areas of Nepal. Besides, strengthening mushroom production across the country could be the best alternative agriculture business and employment opportunities in the rural areas, and best way of income generation for disadvantageous groups and small family farms. The study revealed that corn cob substrate with rice bran supplement showed the superior mycelia growth, faster spawn run and better yield among all the treatments including control. Corn cob supplemented with rice bran could be alternate substrate for the cultivation of $P$. ostreatus. Rice bran can be used as the best supplement for the cultivation of Oyster mushroom.

\section{ACKNOWLEDGMENTS}

The study was supported by Nepal Academy of Science and Technology (NAST), Khumaltar, Lalitpur, Nepal. The author appreciates the valuable contribution and work provided by Mr. Anand Joshi.

\section{REFERENCES}

Adejoye, O. D. Adebayo-Tayo, B. C., Ogunjobi, A. A., and Olaoye, O. A. 2006. Effect of Carbon, Nitrogen and mineral sources on growth of Pleurotus florida, Nigeria edible mushroom. African Journal of Biotechnology, 5:1355-1359.

Basyal, E. Perker, H. Yalinkilic M. K. and Temiz A. 2003. Cultivation of oyster mushroom on waste paper with some added supplementary materials. Bio-resource Technology 89: 95- 97. 
Celik, Y. and Pekker, K. 2009. Benefit/Cost analysis of mushroom production for diversification of income in developing countries. Bulgarian Journal of Agricultural Science 15(3): 228-237.

Das, N. and Mukherjee, M. 2007. Cultivation of Pleurotus ostreatus on weed plants, BioResources Technology 98(14): 2723-2726.

Jenning, D. H. and Lysek, G. 1999. Fungal Biology: Understanding the fungal lifecycle. Bios Scientific Publishers, New York.

Madan, M. Vasudevan, P. and Sharma, S. 1987. Cultivation of Pleurotus sajar-caju on different wastes. Biological Wastes 22: 241-250.

Martinez, A. T., Camarero, S., Guillen, F., Gutierrez, A., Munoz, C., Varela, E., et al. 1994. Progress in bio-pulping of non-woody materials-chemicals, enzymatic and ultra structural aspect of wheat straw delignification with lignolytic fungi from the genus Pleurotus. FEMS Microbiological Reviews 13: 265-274.

Mueller, J. C. and Gawley, J. R. 1983. Cultivation of Phoenix Mushrooms on Pulp Mill Sludge's. Mushroom Newsletter for the Tropics 4: 3-17.

Pidgeon, E. R. and Anderson R. W. 1981. Demand trend in Canada's mushroom industry. Canadian Farm Economics 116: 1-6.

Philippoussis, A., Zervakis, G. and Diamentopoulou, P. 2006. Bio- conversion of lignocellulosic waste through the cultivation of the edible mushroom. Agrocybe Publication.

Pokhrel, C. P., Kalyan, N., Budathoki, U., Yadav, R. K. P. 2013. Cultivation of Pleurotus sajorcaju using different agricultural residues. International Journal of Agricultural Policy and Research 2:19-23.

Pokhrel C. P. Yadav, R. K. P. and Ohga S. 2009. Effects of physical factors and synthetic media on mycelial growth of Lyophyllum decastes. Journal of Ecobiotech 1: 046-050.

Pokhrel, C. P. Sumikawa, S. Iida S. and Ohga, S. 2006. Growth and Productivity of Lyophyllum decastes on compost enriched with various supplements. Micologia Applicada International 18(2): 21-28 .

Sharma, S. Yadav, R. K. P. and Pokhrel, C. P. 2013. Growth and Yield of Oyster mushroom (Pleurotus Osteratus0 on different Substrate. Journal of New Biological Reports 2 (1):3-8.

Tan, K. K. 1981. Cotton waste as a good substrate for cultivation of Pleurotus ostreatus. The Oyster Mushroom. Mushroom Science 11(1): 705-710.

Zadrazil, F. and Kurtzman, R. H. 1981. The Biology of Pleurotus cultivation in tropics. In: Chang, S. T., Quimio, T. H.(eds), Tropical mushroom, The Chinese University Press, Shatin, Hong Kong, pp. 493.

Zhang, R., Li, X. and Fadel, J. G. 2002. Oyster mushroom cultivation with rice and wheat straw. Bio-resource Technology 82: 277-284. 